\title{
A Gerbode-like defect associated with Ebstein's anomaly in an adult patient
}

\author{
Soumya Patra, Ravindranath K Shankarappa, Satish Karur, Navin Agrawal
}

Department of Cardiology, Sri Jayadeva Institute of Cardiovascular Sciences \& Research, Bangalore, Karnataka, India

\section{Correspondence to} Dr Navin Agrawal,

drnavinagrawal@gmail.com

\section{DESCRIPTION}

We report the case of a 42-year-old man who presented with effort intolerance of New York Heart Association (NYHA) class II for the past 1 year. On clinical examination, there was presence of cyanosis, clubbing, ejection systolic murmur of grade III/VI at left lower parasternal area, splitting of both first and second heart sound and fourth heart sound. An echocardiography revealed apical displacement of the septal leaflet of the tricuspid valve by about $37 \mathrm{~mm}$ (figure 1, video 1) and presence of tricuspid regurgitation (TR) with a TR jet of $49 \mathrm{~mm} \mathrm{Hg}$ (figure 2). There was presence of Gerbode-like defect with perimembranous ventricular septal defect (VSD) of $5 \mathrm{~mm}$ connecting the left ventricle (LV) to the right atrium (RA) with left to right shunt (figure 3, video 2). A persistent foramen ovale of $2 \mathrm{~mm}$ with right to left shunt was also associated with Ebstein's anomaly in our case and it was also the cause for cyanosis and clubbing

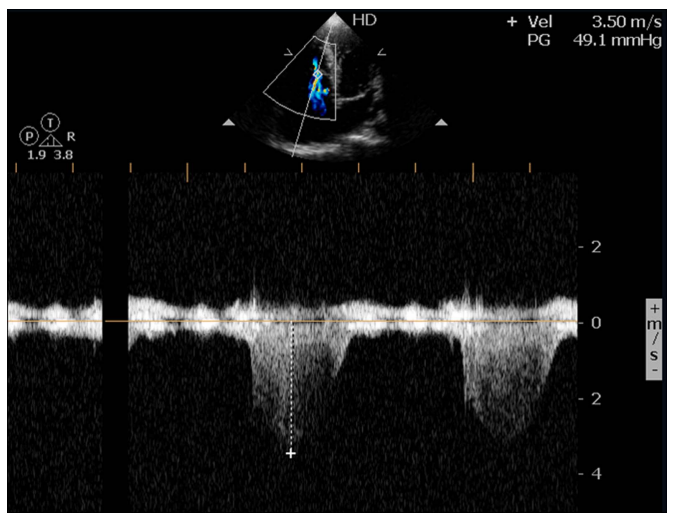

Figure 1 Apical 4C view revealed apical displacement of the septal leaflet of the tricuspid valve by $37 \mathrm{~mm}$.

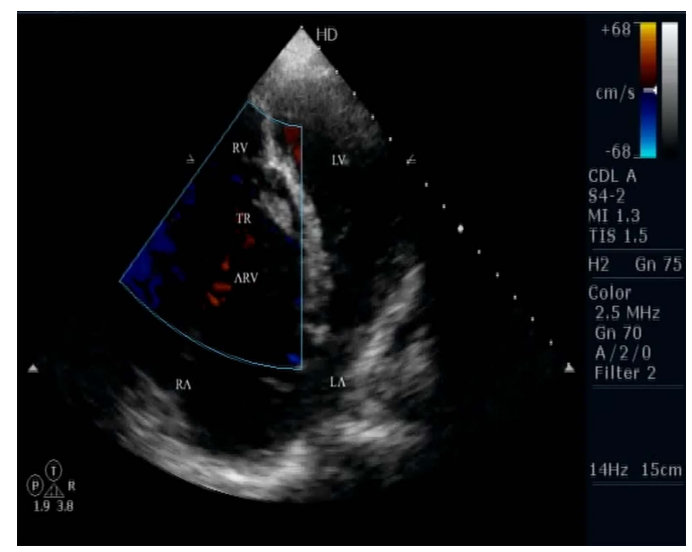

Video 1 Apical 4C view revealed apical displacement of septal leaflet of tricuspid valve with TR.

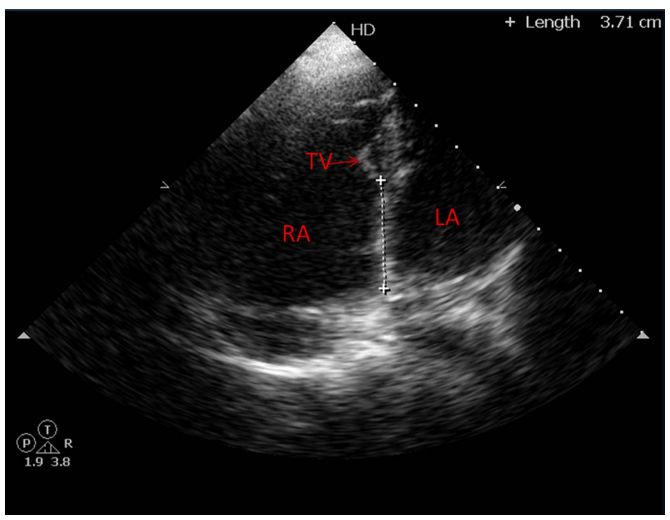

Figure 2 Colour Doppler showed a TR jet of $49 \mathrm{~mm} \mathrm{Hg}$ originating from apically displaced tricuspid valve leaflets.
To cite: Patra $S$

Shankarappa RK, Karur S, et al. BMJ Case Rep Published online: [please include Day Month Year] doi:10.1136/bcr-2013200721

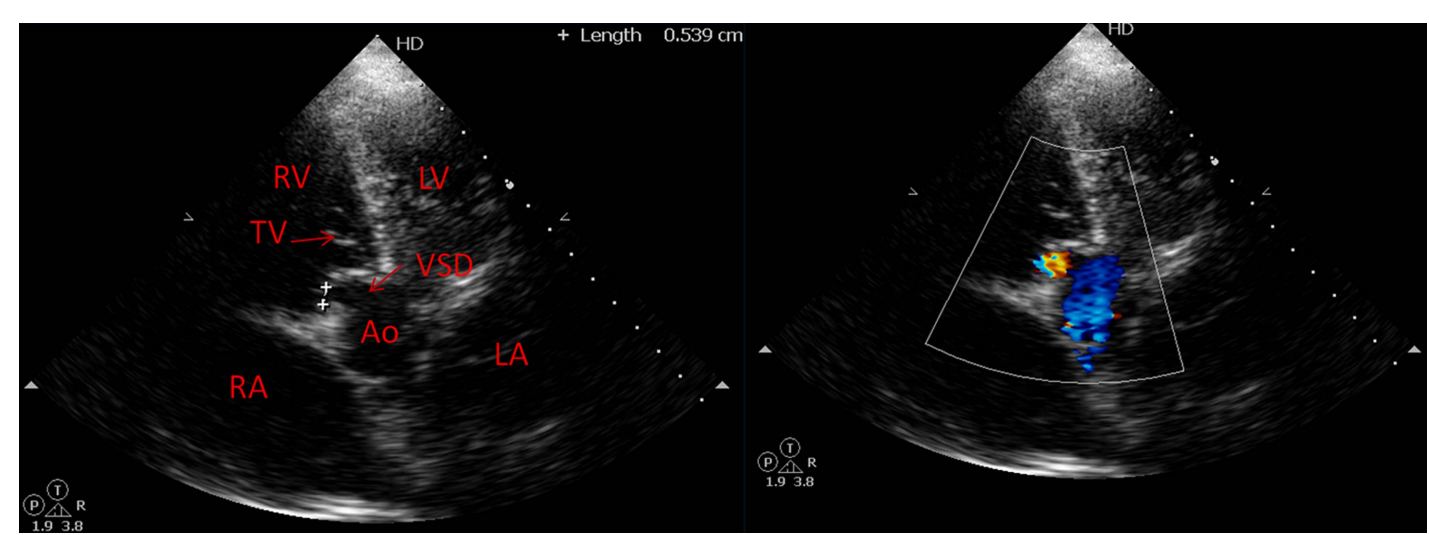

Figure 3 Colour Doppler at apical 5C view showed presence of Gerbode-like communication with perimembranous ventricular septal defect connecting between left ventricle and right atrium. 


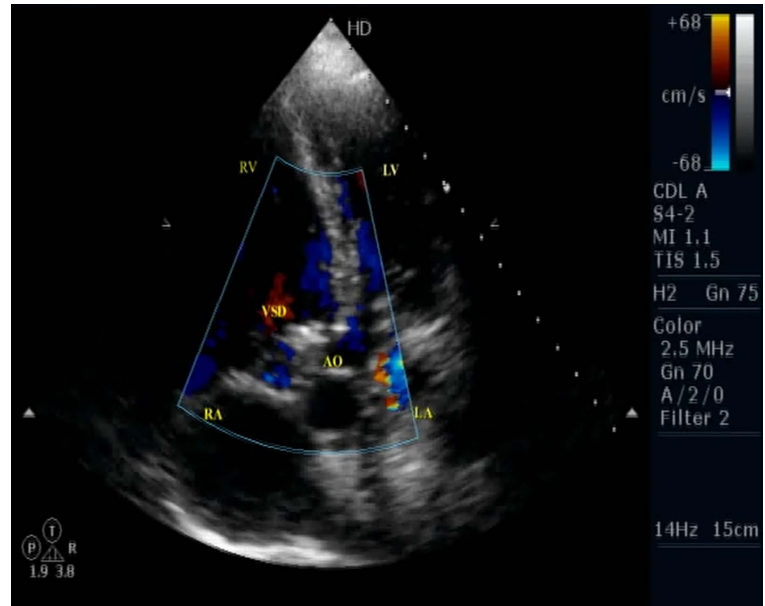

Video 2 Apical 5C view showed presence of VSD between LV \& RA with left to right shunt.

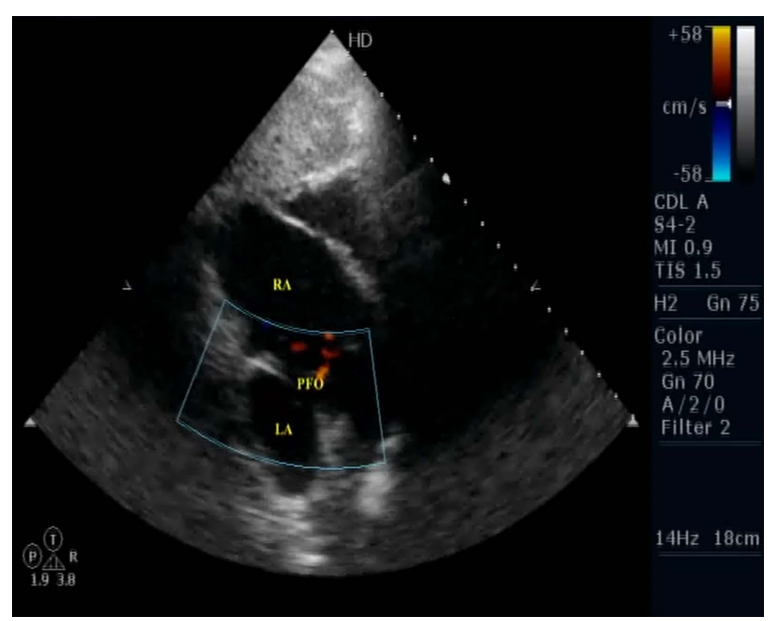

Video 3 Subcostal view showed presence of PFO with right to left shunt. in our case (video 3). So, in our case Gerbode-like VSD was associated with Ebstein's anomaly. This kind of VSD is rarely associated with Ebstein's anomaly. So far only one case has been reported in the literature where Gerbode-type VSD was associated with Ebstein's anomaly along with Wolff-ParkinsonWhite syndrome. ${ }^{1}$ But, in our case this adult patient has cyanosis and significant effort intolerance without any arrhythmia. It is speculated that this rare association, allowing LV to RA flow will cause RA volume overload and will increase right to left shunt and that is why he had significant cyanosis and NYHA class II symptoms at presentation. In contrast, when there is a connection between the LV to the right ventricle, adequate forward pulmonary blood flow will be seen and these kinds of patients reported to have favourable prognosis. ${ }^{2}$

\section{Learning points}

- Ebstein's anomaly is a rare congenital heart defect associated with apical displacement of septal leaflet of tricuspid valve.

- Patent foramen ovale and ostium secundum atrial septal defect are most commonly associated lesions with Ebstein's anomaly.

- Gerbode's defect, which is a connection between left ventricle and right atrium, rarely associated with Ebstein's anomaly.

Contributors All authors were involved in the management of this patient. Competing interests None.

Patient consent Obtained.

Provenance and peer review Not commissioned; externally peer reviewed.

\section{REFERENCES}

1 Bayar N, Canbay A, Uçar O, et al. Association of Gerbode-type defect and Wolff-Parkinson-White syndrome with Ebstein's anomaly. Anadolu Kardiyol Derg 2010;10:88-90.

2 Del Pasqua A, de Zorzi A, Sanders SP, et al. Severe Ebstein's anomaly can benefit from a small ventricular septal defect: two cases. Pediatr Cardiol 2008;29:217-19.

Copyright 2013 BMJ Publishing Group. All rights reserved. For permission to reuse any of this content visit

http://group.bmj.com/group/rights-licensing/permissions.

BMJ Case Report Fellows may re-use this article for personal use and teaching without any further permission.

Become a Fellow of BMJ Case Reports today and you can:

- Submit as many cases as you like

- Enjoy fast sympathetic peer review and rapid publication of accepted articles

- Access all the published articles

- Re-use any of the published material for personal use and teaching without further permission

For information on Institutional Fellowships contact consortiasales@bmjgroup.com

Visit casereports.bmj.com for more articles like this and to become a Fellow 